\title{
Correction: Outcomes of the Ontario Bariatric Network: a cohort study
}

In an article published July $27,2016,{ }^{1}$ a word was missing from the title. "Outcomes the Ontario Bariatric Network: a cohort study" should have been "Outcomes of the Ontario Bariatric Network: a cohort study." The article has been corrected at cmajopen.ca.

\section{Reference}

1. Saleh F, Doumouras AG, Gmora S, et al. Outcomes of the Ontario Bariatric Network: a cohort study. CMA7 Open 2016;4:E383-9.

CMAJ Open 2021. DOI:10.9778/cmajo.20210040 